\title{
Original Artikel \\ Analisis Implementasi Sistem Proteksi Kebakaran Aktif, Sarana Penyelamatan Jiwa Dan Tanggap Darurat Di Gedung Promoter Polda Metro Jaya Tahun 2021 \\ (Analysis of the Implementation of Fire Protection Active System, Life Saving Equipment, and Emergency Response in Promoter Polda Metro Jaya Building 2021)
}

\author{
Ilham Bintoro ${ }^{1}$, Agus Triyono ${ }^{2}$ \\ STIKIM Jakarta, Indonesia \\ Ilhambintoronew@gmail.com
}

\begin{abstract}
Introduction: Promoter Polda Metro Jaya Building is one of the state-owned buildings which must complete Occupational Health and Safety (OHS) requirements, have a fire protection system, life saving equipment, and emergency response due to the regulation. The purpose of this research is to know The Impelentation of The Fire Protection Active System, Life Saving Equipment, and Emergency Response at Promoter Polda Metro Jaya Building according to Ministerial Regulation No. 262008.
\end{abstract}

Methods: This research is a qualitative research using triangulation method by interviewing, observating, and resourcing. The Informants of this research are Head of Managing Coordinator, Technician Supervisor, and The Technicians.

Results: The results of the research are the implementation of fire protection active system has already appropriated to Ministerial Regulation No. 262008 with 90,5\% suitability, the implementation of life saving equipment has already appropriated to Ministerial Regulation No. 262008 with 94\% suitability, the implementation of fire emergency response has already appropriated to Ministerial Decree 186/MEN/1999 with 46,15\% suitability.

Discussion: The suggestions according to priority scale are the manager makes a policy about the prevention and repression of the fire disaster, SOP of emergency response, forms emergency response team, and maintains, checks, and evaluates the fire protection active system and life saving equipment regularly.

Keywords: Fire Protection Active System, Life Saving Equipment, Emergency Response

\author{
Artikel \\ Disubmit (Received) : 25 September 2021 \\ Diterima (Accepted) : 12 Oktober 2021 \\ Diterbitkan (Published) : 21 Oktober 2021
}

Copyright: (C) 2021 by the authors. License DPOAJ, Jakarta, Indonesia. This article is an open access article distributed under the terms and conditions of the Creative Commons Attribution (CC BY SA) license (https:// creativecommons.org/licenses/by/4.0/) 


\section{Pendahuluan}

Pesatnya perkembangan ekonomi dan permintaan kebutuhan masyarakat khususnya di DKI Jakarta telah mendorong pemerintah untuk membangun gedung-gedung sebagai pusat kegiatan seperti perkantoran, perbelanjaan, dan tempat tinggal. ${ }^{1}$ Bangunan gedung perkantoran dihadapkan dengan berbagai risiko bahaya keadaan darurat seperti kebakaran, gempa, banjir dan lain-lain. ${ }^{2}$ Kebakaran menurut National Fire Protection Association merupakan suatu peristiwa oksidasi dalam suatu waktu bertemu tiga buah unsur, yakni bahan yang mudah terbakar, oksigen, dan panas yang dapat berakibat menimbulkan kerugian harta benda atau cedera bahkan kematian manusia. ${ }^{3}$ Penyebab kebakaran terdiri dari berbagai faktor, namun sering diakibatkan oleh adanya human error atau unsafe action dan unsafe condition. ${ }^{3}$

Berdasarkan Data United State Fire Departements tahun 2018 menanggapi sekitar 1.318.500 kasus kebakaran. Kebakaran ini mengakibatkan 3.655 korban jiwa meninggal dunia akibat kebakaran, 15.200 cedera akibat kebakaran, dan mengalami kerugian sekitar \$25.6 miliar, angka ini termasuk kerugian \$12.4 miliar dari kebakaran hutan besar California. Rata-rata, ada kematian akibat kebakaran setiap 2 jam 24 menit dan cedera akibat kebakaran setiap 35 menit pada tahun 2018. ${ }^{4}$ Berdasarkan data yang dihimpun oleh Dinas Penanggulangan Kebakaran dan Penyelamatan Provinsi DKI Jakarta jumlah kejadian kebakaran di DKI Jakarta pada tahun 2016 - 2020 mencapai 8.081 kejadian. Penyebab terjadinya kebakaran ialah $62 \%$ dari total kejadian kebakaran atau 4.893 kejadian kebakaran diduga akibat Listrik. Kebakaran ini mengakibatkan 136 orang meninggal dunia, dan 584 orang mengalami luka-luka baik dari petugas Dinas Penanggulangan Kebakaran dan Penyelamatan serta masyarakat yang menjadi korban dalam kejadian tersebut. ${ }^{5}$

Menurut Undang-undang No. 28 Tahun 2002 tentang bangunan gedung, faktor keselamatan adalah suatu syarat yang harus dipenuhi oleh bangunan gedung, dimana kebakaran merupakan salah satu aspeknya. Bangunan gedung diharapkan memiliki sistem proteksi kebakaran yang memenuhi syarat dimana bangunan tersebut mampu mencegah timbulnya api, menjalarnya api dan asap, adanya fasilitas pemadaman api, dan menyediakan sarana evakuasi yang layak bagi penghuni gedung. ${ }^{6}$ Menurut Peraturan Menteri Pekerjaan Umum No. 26/PRT/M/2008 tentang Persyaratan Teknis Sistem Proteksi Kebakaran pada Bangunan Gedung dan Lingkungan, bahwa keselamatan masyarakat yang berada di dalam bangunan dan lingkungannya harus menjadi pertimbangan utama khususnya terhadap bahaya kebakaran, maka suatu bangunan harus memiliki sistem proteksi kebakaran, baik itu aktif maupun pasif, dilengkapi dengan kelengkapan tapak dan sarana penyelamatan jiwa. ${ }^{7}$

Gedung Promoter Polda Metro Jaya termasuk bangunan gedung negara yang harus memenuhi persyaratan K3 dan memiliki sistem proteksi kebakaran, sarana penyelamatan jiwa serta tanggap darurat dari bencana atau keadaan darurat yang sesuai dengan regulasi pemerintah dan SNI yang dipersyaratkan. Gedung Promoter Polda Metro Jaya juga merupakan lembaga penting yang mempunyai tugas dalam keamanan dan ketertiban masyarakat, sehingga banyak berkas penting yang berkaitan dengan keamanan daerah Provinsi DKI Jakarta. ${ }^{8}$ Kepala koordinator pengelola Gedung Promoter Polda Metro Jaya menjelaskan penyediaan sarana proteksi kebakaran dan sarana penyelamatan jiwa telah dilaksanakan sejak Gedung Promoter Polda Metro Jaya diresmikan, yaitu sejak 19 Januari 2018. Tanggap darurat kebakaran di Gedung Promoter Polda Metro Jaya merupakan tugas dan tanggung jawab teknisi gedung. Teknisi bertugas untuk melakukan pemeliharaan dan pengecekan berkala, dan bertugas dalam pelaksanaan di lapangan dengan sebelumnya dilaksanakan simulasi tanggap darurat bersama. Belum pernah dilakukan analisis implementasi sistem proteksi kebakaran aktif, sarana penyelamatan jiwa serta tanggap darurat pada Gedung Promoter Polda Metro Jaya.

Gedung Promoter Polda Metro Jaya merupakan gedung bertingkat yang berfungsi sebagai perkantoran dan terdiri dari 24 lantai. Gedung tersebut terdiri dari empat lift untuk mengakomodir 


\section{DPOAJ}

\section{Dohara Publisher Open Access Journal}

Volume 01, No.02, Oktober.2021 e-ISSN 2807-7539, p-ISSN 2807-7547

mobilitas karyawan, dan satu lift service yang digunakan untuk tim pemadam kebakaran saat terjadi kebakaran. Gedung Promoter Polda Metro Jaya telah dilengkapi dengan sistem proteksi kebakaran aktif berupa alarm kebakaran, detektor kebakaran, alat pemadam api ringan, hidran, dan sprinkler. Sarana penyelamatan jiwa berupa sarana jalan keluar, pintu darurat, tangga darurat, tempat berhimpun serta lampu darurat. Belum diketahui tingkat kesesuaian implementasi sistem proteksi kebakaran aktif, sarana penyelamatan jiwa serta tanggap darurat, tetapi perawatan rutin dan pemeliharaan dilakukan di Gedung Promoter Polda Metro Jaya. Berdasarkan dari latar belakang diatas, penulis ingin mengetahui implementasi sistem proteksi kebakaran aktif, sarana penyelamatan jiwa dan tanggap darurat yang berada di Gedung Promoter Polda Metro Jaya berdasarkan regulasi Peraturan Menteri Pekerjaan Umum No. 26/PRT/M/2008 Tentang Persyaratan Teknis Sistem Proteksi Kebakaran pada Bangunan Gedung dan Lingkungan.

\section{Metode}

Jenis penelitian ini merupakan penelitian kualitatif. ${ }^{9}$ Populasi dalam penelitian ini ialah pengelola Gedung Promoter Polda Metro Jaya sebanyak empat orang sebagai penanggung jawab dalam pelaksanaan keselamatan Gedung Promoter Polda Metro Jaya. Pengambilan sampel penelitian ini dengan menggunakan cara non probability sampling yaitu metode purposive sampling. Penelitian ini dilaksanakan di Gedung Promoter Polda Metro Jaya yang berlokasi di Jalan Jendral Sudirman No. Kav 55, Senayan, kota Jakarta Selatan. Penelitian ini dilaksanakan pada bulan April sampai dengan bulan Juli 2021. Penelitian menggunakan metode Triangulasi data yaitu dilakukan dengan wawancara mendalam (in-depth interview), observasi atau pengamatan, dan sumber dokumen. ${ }^{10}$

Analisis data kualitatif merupakan proses mengatur urutan data dan mengorganisasikan kedalam suatu pola, kategori dan satuan urutan dasar. ${ }^{11}$ Peneliti menggunakan triangulasi sebagai teknik untuk mengecek keabsahan data. Dimana dalam pengertiannya triangulasi adalah teknik pemeriksaan keabsahan data yang memanfaatkan sesuatu yang lain dalam membandingkan hasil wawancara terhadap objek penelitian. Triangulasi dapat dilakukan dengan menggunakan teknik yang berbeda yaitu wawancara, observasi dan dokumen. ${ }^{12}$

\section{Hasil dan Pembahasan}

\section{Sistem Proteksi Kebakaran Aktif}

Hasil pengambilan data mengenai sistem proteksi kebakaran aktif di Gedung Promoter Polda Metro Jaya dilakukan dengan pengisian lembar checklist observasi pada alarm kebakaran, detektor kebakaran, alat pemadam api ringan, sprinkler dan hidran yang selanjutnya akan diuraikan sebagai berikut:

\section{Alarm Kebakaran}

Berdasarkan observasi penelitian, Gedung Promoter Polda Metro Jaya tidak memiliki gambar instalasi secara lengkap, serta tidak terdapat prosedur pemeliharaan. Pada sistem alarm kebakaran, titik panggil manual diletakan di tempat mudah dicapai dan terlihat jelas. Titik panggil manual diletakan di tempat yang tidak terhalang oleh apapun. Titik panggil manual diletakan di lintasan.

Berdasarkan hasil observasi penelitian yang dibandingkan dengan Peraturan Menteri Pekerjaan Umum No. 26 Tahun 2008, didapatkan hasil kesesuaian Alarm Kebakaran di Gedung Promoter Polda Metro Jaya terdapat 10 persyaratan yang sesuai $(83,3 \%)$ dan terdapat 2 persyaratan yang tidak sesuai $(16,7 \%)$ dari 12 persyaratan. 


\section{DPOA}

Dohara Publisher Open Access Journal

Volume 01, No.02, Oktober.2021

e-ISSN 2807-7539, p-ISSN 2807-7547

\section{Detektor Kebakaran}

Berdasarkan hasil observasi penelitian menggunakan lembar checklist observasi, Gedung Promoter Polda Metro Jaya sudah terpasang detektor kebakaran di seluruh ruangan. Detektor kebakaran pada satu kelompok sistem alarm kebakaran tidak lebih dari 40 buah detektor panas. Di Gedung Promoter Polda Metro Jaya, jarak detektor kebakaran dipasang sebesar 3 meter. Detektor kebakaran di Gedung Promoter Polda Metro Jaya dilakukan pemeliharaan dan pengujian setiap bulan.

Berdasarkan hasil observasi penelitian yang dibandingkan dengan Peraturan Menteri Pekerjaan Umum No. 26 Tahun 2008, didapatkan hasil kesesuaian Detektor Kebakaran di Gedung Promoter Polda Metro Jaya sudah sesuai dengan regulasi Peraturan Menteri Pekerjaan Umum No. 26 Tahun 2008 terdapat 7 persyaratan yang sesuai $(100 \%)$ dari 7 persyaratan.

\section{Alat Pemadam Api Ringan (APAR)}

Berdasarkan hasil observasi dilapangan, APAR yang digunakan di Gedung Promoter Polda Metro Jaya merupakan APAR jenis dry chemical powder dengan klasifikasi pemadaman kelas A dan APAR dengan klasifikasi pemadaman kelas A, B, dan C. APAR diletakan di tempat yang menyolok mata, tidak terhalang, mudah dijangkau dan siap digunakan. APAR dipasang kokoh pada penggantung atau pengikat buatan manufaktur APAR.

Berdasarkan hasil observasi di lapangan, untuk pemeriksaan dan pemeliharaan APAR dilakukan sebulan sekali oleh pihak tenisi Gedung Promoter Polda Metro Jaya dan arsip dari seluruh APAR yang diperiksa disimpan. Setiap APAR di Gedung Promoter Polda Metro Jaya tidak mempunyai kartu atau label yang diletakkan dengan kokoh yang menunjukkan bulan dan tahun dilakukannya pemeliharaan, pada label pemeliharaan tidak terdapat identifikasi petugas.

Berdasarkan hasil observasi penelitian yang dibandingkan dengan Peraturan Menteri Pekerjaan Umum No. 26 Tahun 2008, didapatkan hasil kesesuaian Alat Pemadam Api Ringan (APAR) di Gedung Promoter Polda Metro Jaya terdapat 13 persyaratan yang sesuai $(86,7 \%)$ dan terdapat 2 persyaratan yang tidak sesuai $(13,3 \%)$ dari 15 persyaratan.

\section{Sprinkler}

Berdasarkan hasil observasi penelitian, Gedung Promoter Polda Metro Jaya memiliki sprinkler dengan jumlah 1200 buah yang terpasang di seluruh ruangan Gedung Promoter Polda Metro Jaya. Air yang digunakan untuk sprinkler merupakan air bersih bebas dari bahan kimia serta tidak mengandung serat atau bahan lain yang dapat mengganggu bekerjanya sprinkler. Sistem penyediaan air yang digunakan untuk sprinkler memiliki kapasitas yang cukup, bekerja secara otomatis, dan dapat diandalkan setiap saat.

Berdasarkan hasil observasi penelitian yang dibandingkan dengan Peraturan Menteri Pekerjaan Umum No. 26 Tahun 2008, didapatkan hasil kesesuaian Sprinkler di Gedung Promoter Polda Metro Jaya terdapat 11 persyaratan yang sesuai $(91,7 \%)$ dan terdapat 1 persyaratan yang tidak sesuai $(8,3 \%)$ dari 12 persyaratan.

\section{Hidran}

Berdasarkan hasil observasi penelitian, Gedung Promoter Polda Metro Jaya memiliki 2 jenis hidran, yaitu hidran gedung dan hidran halaman. Hidran gedung berjumlah 2 buah di sisi utara dan sisi selatan pada setiap lantai koridor. Hidran halaman berjumlah 2 buah di area luar Gedung Promoter 


\section{DPOAJ}

Dohara Publisher Open Access Journal

Volume 01, No.02, Oktober.2021

e-ISSN 2807-7539, p-ISSN 2807-7547

Polda Metro Jaya. Kotak hidran dipasang pada dinding beton yang datar dengan ketinggian rata-rata 1 meter di atas permukaan lantai, dan dicat dengan warna merah yang bertuliskan "HYDRANT" yang dicat berwarna putih.

Berdasarkan observasi di lapangan terdapat beberapa temuan yang tidak sesuai dengan Peraturan Menteri Pekerjaan Umum RI No.26/PRT/M/2008, yaitu kondisi hidran terhalang oleh benda termasuk salah satunya kaca. Kotak hidran gedung berisikan selang, sambungan selang, kepala selang dan keran pembuka. Pada hidran halaman, pasokan air untuk hidran halaman sekurang-kurangnya 2400 liter/menit pada tekanan 3,5 bar serta mampu mengalirkan air selama 45 menit. Terdapat sumber daya listrik darurat apabila sumber daya listrik utama tidak bekerja. Hidran pernah dilakukan inspeksi atau pemeriksaan, pengujian dan pemeliharaan oleh pihak pengelola Gedung Promoter Polda Metro Jaya.

Berdasarkan hasil observasi penelitian yang dibandingkan dengan Peraturan Menteri Pekerjaan Umum No. 26 Tahun 2008, didapatkan hasil kesesuaian Hidran di Gedung Promoter Polda Metro Jaya terdapat 10 persyaratan yang sesuai $(90,9 \%)$ dan terdapat 1 persyaratan yang tidak sesuai $(9,1 \%)$ dari 11 persyaratan.

\section{Sarana Penyelamatan Jiwa}

Hasil pengambilan data mengenai sarana penyelamatan jiwa di Gedung Promoter Polda Metro Jaya dilakukan dengan pengisian lembar checklist observasi pada sarana jalan keluar, pintu darurat, tangga darurat, tempat berhimpun, dan lampu darurat yang selanjutnya akan diuraikan sebagai berikut:

\section{Sarana Jalan Keluar}

Berdasarkan observasi penelitian, lebar tangga darurat sebesar 2m, tinggi anak tangga sebesar 19 $\mathrm{cm}$, tinggi pegangan tangga sebesar $75 \mathrm{~cm}$, dan lebar anak tangga $30 \mathrm{~cm}$. Pintu darurat pada sarana jalan keluar Gedung Promoter Polda Metro Jaya dilengkapi dengan pintu tahan api yang dapat menutup otomatis. Gedung Promoter Polda Metro Jaya menggunakan tangga darurat berbentuk zig-zag. Tidak terdapat ventilasi berupa alat penghisap di tangga darurat. Berdasarkan observasi dilapangan, sarana jalan keluar koridor terdapat timbunan barang yang tidak digunakan. Koridor terbuat dari lantai yang tidak licin dan koridor berakhir di pintu keluar.

Berdasarkan hasil observasi penelitian yang dibandingkan dengan Peraturan Menteri Pekerjaan Umum No. 26 Tahun 2008, didapatkan hasil kesesuaian sarana jalan keluar di Gedung Promoter Polda Metro Jaya terdapat 14 persyaratan yang sesuai $(82,4 \%)$ dan terdapat 3 persyaratan yang tidak sesuai $(17,6 \%)$ dari 17 persyaratan.

\section{Pintu Darurat}

Berdasarkan observasi penelitian di Gedung Promoter Polda Metro Jaya memiliki pintu darurat yang sudah tahan api, memiliki lebar pintu darurat sebesar $100 \mathrm{~cm}$, tinggi pintu darurat sebesar $210 \mathrm{~cm}$, pintu darurat dapat menutup secara otomatis serta dilengkapi dengan push bar system, jumlah pintu darurat dalam setiap lantai sebanyak 2 buah serta terdapat petunjuk pintu exit dan terbuka ke arah jalan keluar. Menurut Peraturan Menteri Pekerjaan Umum No. 26 Tahun 2008, didapatkan hasil kesesuaian Pintu Darurat di Gedung Promoter Polda Metro Jaya sudah sesuai dengan regulasi Peraturan Menteri Pekerjaan Umum No. 26 Tahun 2008 terdapat 7 persyaratan yang sesuai (100\%) dari 7 persyaratan. 


\section{DPOA}

\section{Dohara Publisher Open Access Journal}

e-ISSN 2807-7539, p-ISSN 2807-7547

\section{Tangga Darurat}

Berdasarkan observasi penelitian, Gedung Promoter Polda Metro Jaya memiliki fasilitas tangga darurat pada sarana penyelamatan jiwa. Berdasarkan observasi penelitian tangga darurat pada Gedung Promoter Polda Metro Jaya berbentuk zig-zag. memiliki lebar tangga darurat sebesar $110 \mathrm{~cm}$. Memiliki lebar injakan tangga darurat sebesar $30 \mathrm{~cm}$, tinggi pegangan sebesar $110 \mathrm{~cm}$ di atas permukaan lantai, tinggi injakan tangga darurat sebesar $15 \mathrm{~cm}$ dan jumlah anak tangga antar bordes sebanyak 10 buah. Permukaan tangga darurat kasar dan tidak ada penghalang. Tidak terdapat ventilasi pengendalian asap pada tangga darurat di Gedung Promoter Polda Metro Jaya.

Berdasarkan hasil observasi penelitian yang dibandingkan dengan Peraturan Menteri Pekerjaan Umum No. 26 Tahun 2008, didapatkan hasil kesesuaian tangga darurat di Gedung Promoter Polda Metro Jaya terdapat 8 persyaratan yang sesuai $(87,5 \%)$ dan terdapat 1 persyaratan yang tidak sesuai $(12,5 \%)$ dari 8 persyaratan.

\section{Tempat Berhimpun}

Berdasarkan observasi penelitian, Gedung Promoter Polda Metro Jaya memiliki 2 tempat berhimpun jika terjadi kebakaran. Tempat berhimpun terletak di area depan gedung promoter tepatnya berada di lahan parkir. Tempat berhimpun sering dijadikan lahan parkiran mobil dan motor, dikarenakan kurangnya lahan untuk parkiran kendaraan bermotor. Untuk area tempat berhimpun sudah diberikan tanda atau plang berupa petunjuk bahwa area tersebut merupakan tempat untuk berhimpun apabila terjadi kebakaran. Kondisi tempat berhimpun aman, mudah dijangkau, dan cukup luas, menampung seluruh karyawan Gedung Promoter Polda Metro Jaya.

Berdasarkan hasil observasi penelitian yang dibandingkan dengan Peraturan Menteri Pekerjaan Umum No. 26 Tahun 2008, didapatkan hasil kesesuaian tempat berhimpun di Gedung Promoter Polda Metro Jaya sudah sesuai dengan regulasi Peraturan Menteri Pekerjaan Umum No. 26 Tahun 2008 terdapat 3 persyaratan yang sesuai $(100 \%)$ dari 3 persyaratan.

\section{Pencahayaan Darurat}

Berdasarkan observasi penelitian, Gedung Promoter Polda Metro Jaya memiliki pencahayaan darurat yang digunakan pada sarana penyelamatan jiwa saat terjadi kondisi darurat. Pencahayaan darurat dipasang di sepanjang jalur evakuasi. Pencahayaan darurat bekerja secara otomatis, apabila listrik PLN padam sumber listrik berasal dari genset. Kemampuan baterai bertahan selama kurang lebih 90 menit. Dan untuk waktu peralihan minimal 10 detik. Pengujian dan pemeliharaan fungsi pencahayaan darurat dilakukan setiap bulan.

Berdasarkan hasil observasi penelitian yang dibandingkan dengan Peraturan Menteri Pekerjaan Umum No. 26 Tahun 2008, didapatkan hasil kesesuaian pencahayaan darurat di Gedung Promoter Polda Metro Jaya sudah sesuai dengan regulasi Peraturan Menteri Pekerjaan Umum No. 26 Tahun 2008 terdapat 8 persyaratan yang sesuai $(100 \%)$ dari 8 persyaratan.

\section{Tanggap Darurat Kebakaran}

Berdasarkan informasi dari berbagai informan di Gedung Promoter Polda Metro Jaya mengenai tanggap darurat kebakaran, Gedung Promoter Polda Metro Jaya belum memiliki kebijakan mengenai pencegahan dan penanggulangan kebakaran secara tertulis dan terstruktur, belum memiliki SOP mengenai pencegahan kebakaran, serta belum memiliki tim tanggap darurat untuk menanggulangi kejadian kebakaran di Gedung Promoter Polda Metro Jaya. Gedung Promoter Polda Metro Jaya belum memiliki prosedur proses evakuasi secara tertulis serta belum memiliki peta evakuasi. Mengenai 
pemeliharaan, perawatan dan pengujian sarana dan prasarana keselamatan kebakaran di Gedung Promoter Polda Metro Jaya, dilaksanakan oleh petugas teknisi PT. Cahaya Bandung Promonusa selaku pengelola Gedung Promoter Polda Metro Jaya. Berdasarkan hasil wawancara mengenai tanggap darurat dibandingkan dengan Keputusan Menteri Tenaga Kerja Republik Indonesia No. Kep.186/MEN/1999 mendapatkan tingkat kesesuaian 46,15\%.

Tabel 1. Validasi Hasil Penelitian "Analisis Implementasi Sistem Proteksi Kebakaran Aktif, Sarana Penyelamatan Jiwa Dan Tanggap Darurat Di Gedung Promoter Polda Metro Jaya Tahun 2021".

\begin{tabular}{llccc}
\hline No & \multicolumn{1}{c}{ Variabel } & Observasi & Wawancara & Studi Dokumentasi \\
\hline 1. & Sistem Proteksi Kebakaran Aktif & $\checkmark$ & X & $\checkmark$ \\
a. Alarm Kebakaran & $\checkmark$ & X & $\checkmark$ \\
b. Detektor Kebakaran & $\checkmark$ & X & $\checkmark$ \\
c. Alat Pemadam Api Ringan & $\checkmark$ & X & $\checkmark$ \\
d. Sprinkler & $\checkmark$ & X & $\checkmark$ \\
e. Hidran & $\checkmark$ & X & $\checkmark$ \\
2. Sarana Penyelamatan Jiwa & $\checkmark$ & X & $\checkmark$ \\
a. Sarana Jalan Keluar & $\checkmark$ & X & $\checkmark$ \\
b. Pintu Darurat & $\checkmark$ & X & $\checkmark$ \\
c. Tangga Darurat & $\checkmark$ & X & $\checkmark$ \\
d. Tempat Berhimpun & $\checkmark$ & X & $\checkmark$ \\
e. Lampu Darurat & $\checkmark$ & $X$ & $\checkmark$ \\
Tanggap Darurat Kebakaran & $X$ & $\checkmark$ & $\checkmark$ \\
\hline
\end{tabular}

Tabel 2. Rangkuman Hasil Pengambilan Data Mengenai Analisis Implementasi Sistem Proteksi Kebakaran Aktif, Sarana Penyelamatan Jiwa Dan Tanggap Darurat Di Gedung Promoter Polda Metro Jaya Tahun 2021 berdasarkan Peraturan Menteri Pekerjaan Umum No. 26 Tahun 2008

\begin{tabular}{|c|c|c|c|c|}
\hline No. & Variabel & $\begin{array}{c}\text { Skor yang } \\
\text { diharapkan }\end{array}$ & Hasil ukur & Presentase \\
\hline
\end{tabular}

1. Sistem Proteksi Kebakaran Aktif
a. Alarm Kebakaran
12
10
$83,3 \%$
b. Detektor Kebakaran
7
c. Alat Pemadam Api Ringan
15
7
$100 \%$
d. Sprinkler
12
13
$86,7 \%$
e. Hidran
11
11
$91,7 \%$
$90,9 \%$
Total rata-rata kesesuaian sistem proteksi kebakaran aktif $(\%) \quad 90,5 \%$

2. Sarana Penyelamatan Jiwa
a. Sarana Jalan Keluar
17
14
$82,4 \%$
b. Pintu Darurat
7
c. Tangga Darurat
8
d. Tempat Berhimpun
3
e. Lampu Darurat
$8 \quad 8$
$100 \%$
$87,5 \%$
$100 \%$
$100 \%$
Total rata-rata kesesuaian sarana penyelamatan jiwa (\%)
$94 \%$

3. Tanggap Darurat Kebakaran

Unit Penanggulangan

13

6

$46,15 \%$

Kebakaran 


\section{DPOA}

\section{Kesimpulan}

Berdasarkan hasil penelitian dan pembahasan di atas, mengenai Peraturan Menteri Pekerjaan Umum No. 26 Tahun 2008 pada Gedung Promoter Polda Metro Jaya, maka dapat diambil suatu kesimpulan Analisis Implementasi Sistem Proteksi Kebakaran Aktif, Sarana Penyelamatan Jiwa Dan Tanggap Darurat Di Gedung Promoter Polda Metro Jaya pada tahun 2021, adalah sebagai berikut:

1. Implementasi Sistem Proteksi Kebakaran Aktif sesuai dengan Peraturan Menteri Pekerjaan Umum No. 26 Tahun 2008 di Gedung Promoter Polda Metro Jaya Tahun 2021mendapatkan tingkat kesesuaian $90,5 \%$.

2. Implementasi Sarana Penyelamatan Jiwa sesuai dengan Peraturan Menteri Pekerjaan Umum No. 26 Tahun 2008 di Gedung Promoter Polda Metro Jaya Tahun 2021 mendapatkan tingkat kesesuaian $94 \%$.

3. Implementasi Tanggap Darurat Kebakaran sesuai dengan Keputusan Menteri Tenaga Kerja Republik Indonesia No. Kep.186/MEN/1999 di Gedung Polda Metro Jaya Tahun 2021 mendapatkan tingkat kesesuaian $46,15 \%$.

\section{Saran}

Berdasarkan hasil penelitian yang telah dilakukan di Gedung Promoter Polda Metro Jaya, peneliti memberikan saran sesuai dengan skala prioritas diantaranya sebagai berikut:

1. Perlu ditingkatkan Implementasi Tanggap Darurat Kebakaran di Gedung Promoter Polda Metro antara lain sebagai berikut diharapkan kepada pengelola Gedung Promoter Polda Metro Jaya untuk membuatan kebijakan mengenai pencegahan dan penanggulangan kebakaran, membuat standar operasional prosedur tanggap darurat kebakaran, membuat tim tanggap darurat kebakaran, membuat prosedur proses evakuasi, membuat peta evakuasi, melakukan simulasi tanggap darurat kebakaran dan melakukan sosialisasi tanggap darurat kebakaran kepada seluruh penghuni

2. Perlu ditingkatkan Implementasi Sistem Proteksi Kebakaran Aktif di Gedung Promoter Polda Metro Jaya antara lain sebagai berikut diharapkan kepada pengelola Gedung Promoter Polda Metro Jaya untuk memberikan kartu atau label pemeliharaan pada APAR dan label pemeliharaan identifikasi petugas, memindahkan barang atau benda yang menghalangi Hidran gedung dan mengecat kembali Hidran halaman yang sudah pudar dan melakukan pemeliharaan, pemeriksaan, dan pengujian secara rutin mengenai sistem proteksi kebakaran aktif.

3. Perlu ditingkatkan Implementasi Sarana Penyelamatan Jiwa di Gedung Promoter Polda Metro Jaya antara lain sebagai berikut diharapkan untuk memindahkan tumpukan barang yang tidak digunakan pada jalur evakuasi, untuk memberikan petunjuk tingkatan lantai di tangga darurat, memberikan rambu tempat berhimpun dan melakukan pemeliharaan, pemeriksaan, dan pengujian pada sarana penyelamatan jiwa.

\section{References}

1. Novrikasari, Lestari M, Andarini D, Camelia A, Fujianti P, Putri DA, et al. Penerapan Tanggap Darurat pada Pengunjung Salah Satu Mall di Kota Palembang. Hear J Kesehat Masy. 2021;9(1):18.

2. Gultom TH, Kurniawan B, Lestantyo D. Analisis Keandalan Sistem Keselamatan Bangunan Sebagai Proteksi Kebakaran pada Gedung Polda Jawa Tengah. J Kesehat Masy. 2018;6(9).

3. Gogendra G, Andriyani. Analisis Penerapan Sistem Proteksi Kebakaran Pasif dan Sarana Penyelamatan dalam Upaya Program Emergency Response Plan di Jakarta Eye Center Kedoya Tahun 2020. Environ Occup Heal Saf J. 2020; 


\section{DPOAJ}

Dohara Publisher Open Access Journal

Volume 01, No.02, Oktober.2021 e-ISSN 2807-7539, p-ISSN 2807-7547

4. Evarts B. Fire Loss In The United States During 2018. 2019;(October).

5. Jakarta Command Center Dinas Gulkarmat Provinsi DKI Jakarta. Data Kejadian Kebakaran 20162020. 2021;

6. Undang-Undang Republik Indonesia Nomor 28 Tahun 2002. Tentang Bangunan Gedung. UndangUndang [Internet]. 2002;8-11. Available from: http://ciptakarya.pu.go.id/pbl/index.php/preview/37/uu-no-28-tahun-2002-tentang-bangunangedung

7. Peraturan Menteri Pekerjaan Umum. Persyaratan Teknis Sistem Proteksi Kebakaran pada Bangunan Gedung dan Lingkungan. 26/PRT/M/2008 2008.

8. Menteri Pekerjaan Umum Republik Indonesia. Pedoman Teknis Pembangunan Gedung Negara. Peratur Mentri Pekerj Umum No 45/PRT/M/2007. 2007;1:1-14.

9. Handayana M, Suroto S, Kurniawan B. Analisis Manajemen Pelaksanaan Pada Kesiapsiagaan dan Tanggap Darurat di Gedung Perkantoran X. J Kesehat Masy Univ Diponegoro. 2016;4(1):322-31.

10. Arikunto S. Prosedur Penelitian Suatu Pendekatan Praktik. Jakarta: Rineka Cipta; 2019. 413 p.

11. Handoko L, Ashari ML, Dermawan D, Ari M, Paidi. Edukasi Masyarakat dalam Upaya Pencegahan dan Penanggulangan Kebakaran pada Kawasan Pesisir. Semin Master Ppns. 2017;1509:169-72.

12. Lexy J. Moleong. Metodologi Penelitian Kualitatif. Bandung: PT Remaja Rosdakarya; 2013. 